\title{
ANALISIS PENCAPAIAN TUGAS PERKEMBANGAN SISWA SD NEGERI SERAYU YOGYAKARTA
}

\author{
Risma Dina \\ rismadina817@gmail.com
}

STKIP Budidaya

\begin{abstract}
Penelitian tentang Profil Pencapaian Tugas Perkembangan Siswa Kelas V SD Negeri Serayu Yogyakarta merumuskan profil kelompok siswa dalam sepuluh aspek perkembangan. Penelitian ini bertujuan untuk mengetahui gambaran secara empiris mengenai pencapaian tugas perkembangan pada siswa kelas V SD Negeri Serayu Yogyakarta. Pendekatan yang digunakan adalah pendekatan kuantitatif dengan metode deskriptif. Populasi dalam penelitian ini adalah 77 siswa kelas V SD Negeri Serayu Yogyakarta. Teknik yang digunakan adalah teknik sampling jenuh, yaitu semua anggota populasi dijadikan sebagai sampel. Instrumen pengumpulan data tentang profil pencapaian tugas perkembangan adalah Inventori Tugas Perkembangan (ITP) dengan menggunakan software ATP versi 3.5.6. Hasil penelitian ini menunjukkan bahwa tingkat perkembangan siswa kelas V SD Negeri Serayu Yogyakarta berada pada tingkat konformistik dengan rata-rata tingkat perkembangan 3,12, simpangan baku 0,10 , dan koefisien variansi 3,25\%. Maka dari itu perlu adanya bantuan khusus kepada siswa agar siswa mencapai perkembangan yang ideal yaitu pada tingkat perkembangan sadar diri.
\end{abstract}

Kata kunci : pencapaian tugas perkembangan, siswa $S D$

\section{PENDAHULUAN}

Masa kanak-kanak tengah dan akhir merupakan masa periode perkembangan dengan rentang usia sekitar 6, 10 sampai 11 tahun, dimana anak-anak berada pada tingkatan sekolah dasar. Selama periode ini, anak-anak menguasai keterampilan dasar membaca, menulis, dan berhitung, dan anak-anak akan berhadapan dengan lingkungan yang lebih luas di daerah sekitarnya. Selanjutnya pencapaian dunia anak menjadi lebih sentral, dan kontrol diri semakin meningkat, (Santrock, 2013:16).

Tugas-tugas merupakan suatu tugas yang muncul pada periode tertentu dalam rentang kehidupan individu, yang apabila tugas itu dapat berhasil dituntaskan akan membawa kebahagiaan dan kesuksesan dalam menuntaskan tugas berikutnya, sementara apabila gagal, maka akan menyebabkan ketidakbahagiaan pada diri individu yang bersangkutan,menimbulkan penolakan masyarakat, dan kesulitan-kesulitan dalam menuntaskan tugas-tugas berikutnya, Havighurst (Yusuf:2014-65).

Kondisi perkembangan optimum adalah kondisi dinamis yang ditandai dengan kesiapan dan kemampuan individu untuk memperbaiki diri (self-improvement) agar dia menjadi pribadi yang berfungsi penuh (fullyfungctioning) di dalam lingkungannya (Kartadinata, 2011:57). Peserta didik pada usia sekolah dasar ini tentu saja sangat membutuhkan pendampingan baik dari orang tua maupun guru disekolah.

Penelitian yang dilakukan oleh Virani, Riastini dan Suarjana (2016) tentang deskripsi sikap sosial pada peserta didik kelas IV SD Negeri Penarukan Kecamatan Buleleng Kabupaten Buleleng menunjukkan sikap sosial peserta didik pada aspek disiplin $10 \%$ peserta didik masih belum memakai seragam lengkap dan rapi, 32\% peserta didik datang terlambat dan tidak mengerjakan tugas, dan pada aspek 
santun $12 \%$ peserta didik masih berkata kasar. Selanjutnya, aspek percaya diri masih dikategorikan cukup, yakni ditandai dengan kurang beraninya peserta didik tampil di depan kelas, malu untuk mengungkapkan pendapat, dan malu untuk mengerjakan tugas atau soal di papan tulis. Melihat fenomena di atas hal ini sangat di sayangkan, mengingat masih banyaknya permasalahan-permasalahan yang dialami peserta didik dalam aspek perkembangannya.

Selanjutnya penelitian yang dilakukan oleh Latifa (2017) tentang aspek perkembangan pada anak SD : masalah dan perkembangannya. Hasil penelitian menunjukkan bahwa aspek perkembangan sangat berpengaruh terhadap proses belajar mengajar di kelas. Penelitian ini menunjukkan bahwa aspek perkembangan pada peserta didik sangat penting untuk diperhatikan karena tahapan perkembangan penting dan bahkan fundamental bagi kesuksesan perkembangan peserta didik ke tahap selanjutnya.

Loevinger (Gilmore \& Durkin, 2012) merumuskan bangun perkembangan diri yang meliputi : (1) Presocial and Symbiotic, (2) Impulsive, (3) Self-Protective, (4) Conformist, (5) Self-Aware,(6) Conscientious, Individualistic, (8) Autonomous, (9) Integrated. Tingkat pertama pra-sosial merupakan tingkatan dimana individu belum mampu membedakan diri dengan lingkungan, dan tingkatan terakhir yaitu integrated adalah tingkatan yang jarang dicapai oleh orang. Teori perkembangan diri dari Loevinger dipilih sebagai kerangka kerja teoritik dalam mengembangkan inventori tugas-tugas perkembangan.

Guru hendaknya memahami perkembangan peserta didik sehingga guru dapat berupaya secara optimal dalam mengembangkan aspek perkembangan peserta didik. Semakin banyak para guru dalam mempelajari tentang perkembangan peserta didik maka diperkirakan akan semakin baik para guru dalam membimbing peserta didik. Azam (2016:2).

Gibson \& Mitchell

(2011:567)

mengemukakan need assesment adalah kunci bagi perencanaan yang sukses pada sebuah tujuan. Perumusan program bimbingan dan konseling yang meliputi struktur, isi serta materi program harus disesuaikan dengan kondisi kebutuhan peserta didik dan kondisi sekolah tersebut (Dahir and Stone, 2012:173).

Sesuai dengan uraian di atas, peneliti berupaya untuk mengidentifikasi profil pencapaian tugas perkembangan siswa di SD dengan bantuan software Analisis Tugas Perkembangan (ATP).

Penyusunan ITP terutama dimaksudkan untuk menunjangkegiatan bimbingan dan konseling di sekolah, namun dapat juga digunakan untuk mengetahui tingkat perkembangan anak-anak dan pemuda pada umumnya (Gumilang, 2017: 200).

Berdasarkan hasil analisis ITP dapat disusun program bimbingan dan konseling yang diharapkan peserta didik dapat mencapai tingkat perkembangan yang ideal baik dalam bidang pribadi, belajar, karir, belajar dan sosial.

\section{METODE PENELITIAN}

Penelitian dilakukan dengan menggunakan metode deskriptif kuantitatif untuk mendapatkan gambar empiris. Populasi dalam penelitian ini adalah 77 siswa kelas V SD Negei Serayu Yogyakarta. Teknik yang digunakan adalah teknik sampling jenuh, yaitu semua anggota populasi dijadikan sebagai sampel. Instrumen pengumpulan menggunakan Inventarisasi Tugas Pengembangan yang terdiri dari 50 item pernyataan dengan 4 opsi. Dan pernyataan tersebut dikelompokkan menjadi 10 aspek pembangunan. Setelah itu data dianalisis 
menggunakan Inventori Tugas Perkembangan versi 3.5.6. Interpretasi hasil analisis Tugas Perkembangan harus didasarkan pada teori perkembangan, yaitu teori Loevinger. Untuk tingkat perkembangan siswa sekolah dasar penilaian dimulai dari 1-4. Pertama, tingkat impulsif, kedua tingkat perlindungan diri, ketiga tingkat konformistik, dan keempat tingkat kesadaran diri keempat. Distribusi opsi untuk tugas perkembangan untuk siswa di sekolah dasar dapat dilihat pada tabel di bawah ini

Tabel 1: Sebaran Opsi Tugas Perkembangan Siswa SD

\begin{tabular}{|c|c|c|c|}
\hline No & Indikator & $\begin{array}{l}\text { Sebaran } \\
\text { Item Per- } \\
\text { Rumpun }\end{array}$ & $\begin{array}{l}\sum_{\text {(Opsi) }} \text { Item } \\
\text { (Ops }\end{array}$ \\
\hline 1 & $\begin{array}{l}\text { Landasan hidup } \\
\text { relegius }\end{array}$ & $1,11,21,31$ & 4 \\
\hline 2 & $\begin{array}{l}\text { Landasan perilaku } \\
\text { etis }\end{array}$ & $2,12,22,32$ & 4 \\
\hline 3 & $\begin{array}{l}\text { Kematangan } \\
\text { emosional }\end{array}$ & $3,13,23,33$ & 4 \\
\hline 4 & $\begin{array}{l}\text { Kematangan } \\
\text { intelektual }\end{array}$ & $4,12,24,34$ & 4 \\
\hline 5 & $\begin{array}{l}\text { Kesadaran } \\
\text { tanggung jawab }\end{array}$ & $5,15,25,35$ & 4 \\
\hline 6 & $\begin{array}{lr}\text { Peran } & \text { sosial } \\
\text { sebagai pria dan } \\
\text { wanita }\end{array}$ & $6,12,26,36$ & 4 \\
\hline 7 & $\begin{array}{l}\text { Penerimaan diri } \\
\text { dan } \\
\text { pengembangannya }\end{array}$ & $7,17,27,37$ & 4 \\
\hline 8 & $\begin{array}{l}\text { Kemandirian } \\
\text { perilaku ekonomis }\end{array}$ & $8,18,28,38$ & 4 \\
\hline 9 & $\begin{array}{l}\text { Wawasan } \\
\text { persiapan karir }\end{array}$ & $9,19,29,39$ & 4 \\
\hline 10 & $\begin{array}{l}\text { Kematangan } \\
\text { hubungan dengan } \\
\text { teman sebaya }\end{array}$ & $10,20,30,40$ & 4 \\
\hline
\end{tabular}

\section{HASIL DAN PEMBAHASAN}

Dari hasil pengolahan Analisis Tugas Perkembangan maka dapat diketahui tingkat perkembangan siswa kelas V SD Negeri Serayu Yogyakarta adalah sebagai berikut : 


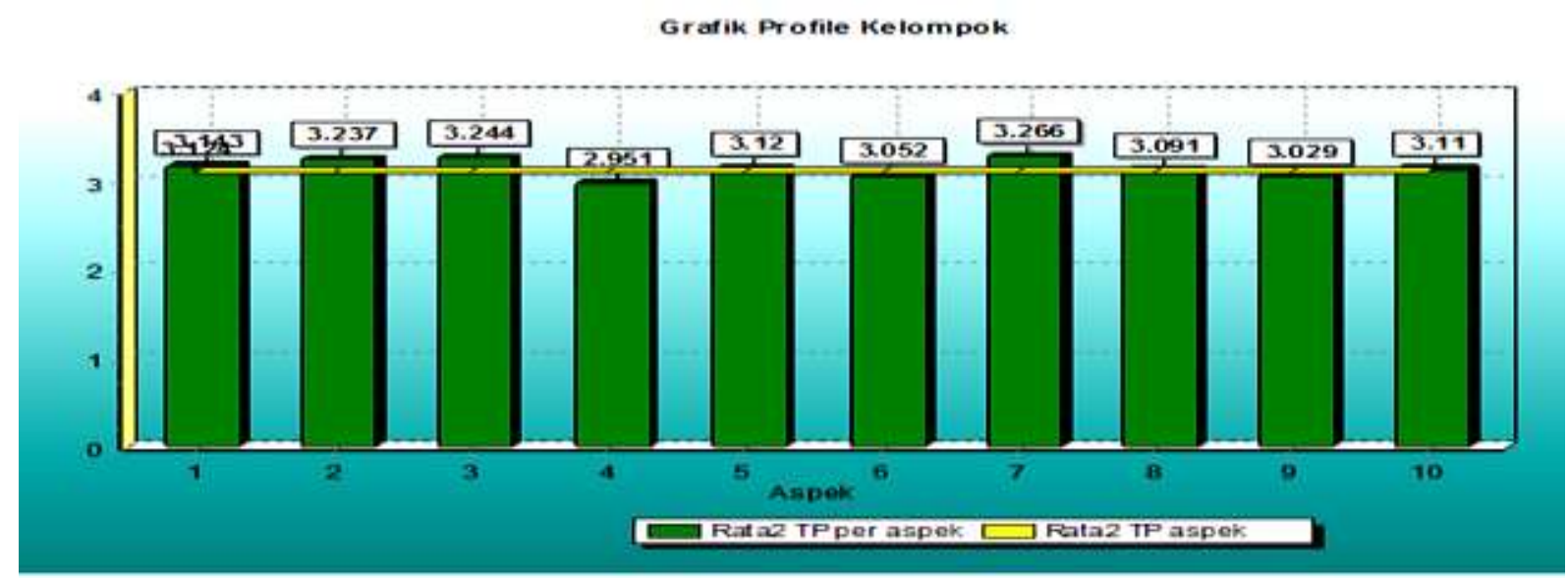

Jumlah peserta: 77

Rata-ra konsistensi: 4.69/10

Rata-rata TP: 3.12

Simpangan baku: 0.10

Koefisien variansi: $3.25 \%$

\section{Keterangan aspek :}

1. Landasan hidup relegius

2. Landasan perilaku etis

3. Kematangan emosional

4. Kematangan intelektual

5. Kesadaran tanggung jawab

6. Peran sosial sebagai pria atau wanita

7. Penerimaan diri dan pengembangannya

8. Kemandirian perilaku ekonomis

9. Wawasan dan persiapan karir

10. Kematangan hubungan dengan teman sebaya

Hasil Analisis Tugas Perkembangan (ATP) di atas menunjukkan profil perkembangan peserta didik kelas V SD Negeri Serayu Yogyakarta dimana dari jumlah peserta didik 77 diketahui rata-rata konsistensi sebesar 4,69/10, rata-rata tingkat perkembangan secara keseluruhan atau kelompok adalah (TP) 3,12 (tingkat konformistik), dimana tingkat perkembangan ini terdiri dari beberapa aspek perkembangan yaitu :
(1) landasan hidup relegius berada pada tingkat perkembangan 3,14 (tingkat konformistik),

(2) landasan perilaku etis berada pada tingkat perkembangan 3,2 (tingkat konformistik),

(3) kematangan emosional berada pada tingkat perkembangan 3,24 (tingkat konformistik),

(4) kematangan intelektual berada pada tingkat 2,95 (tingkat perlindungan diri), 
(5) kesadaran tanggung jawab berada pada tingkat perkembangan 3,12 (tingkat konformistik),

(6) peran sosial sebagai pria atau wanita berada pada tingkat perkembangan 3,05 (tingkat konformistik),

(7) penerimaan diri dan pengembangannya berada pada tingkat perkembangan 3,26 (tingkat konformistik),

(8) kemandirian perilaku ekonomis berada pada tingkat perkembangan 3,09 (tingkat konformistik),

(9) wawasan dan persiapan karir berada pada tingkat perkembangan 3,02 (tingkat konformistik)

(10)dan kematangan hubungan dengan teman sebaya berada pada tingkat perkembangan 3,11 (tingkat konformistik). Selanjutnya simpangan baku 0,10 , dan koefisien variansi $3,25 \%$.

Dapat disimpulkan bahwa tingkat perkembangan peserta didik kelas V SD Negeri Serayu Yogyakarta termasuk dalam kategori Tingkat Konformistik (Kof), karena berada pada rentang ke 3 dengan tingkat perkembangan yaitu 3,12 dengan ciri-ciri tingkat perkembangan ini yaitu: (1) peduli terhadap penampilan diri dan penerimaan sosial, (2) cenderung berfikir stereotip dan klise, (3) peduli akan terhadap aturan eksternal, (4) bertindak dengan motif dangkal ( untuk memperoleh pujian), (5) menyamakan diri dalam ekspresi emosi, (6) kurang intropeksi, (7) perbedaan kelompok didasarkan atas ciriciri eksternal, (8) takut tidak diterima kelompok, (9) tidak sensitif terhadap keindividualan dan (10) merasa berdosa jika melanggar aturan

\section{SIMPULAN}

Dapat disimpulkan secara keseluruhan bahwa hasil dari Analisis Tugas Perkembangan (ATP) menunjukkan bahwa peserta didik kelas V SD Negeri Serayu Yogyakarta termasuk dalam kategori Tingkat Konformitas (Kof) yaitu berada pada tingkat perkembangan 3,12 Seharusnya siswa dapat mencapai perkembangan yang ideal yaitu pada tingkat perkembangan sadar diri dengan ciri-ciri tingkat Sadar diri, memiliki ciriciri sebagai berikut: (1) mampu berfikir alternatif, (2) melihat harapan dan berbagai kemungkinan dalam situasi, (3) peduli untuk mengambil manfaat dari kesempatan yang ada, (4) orientasi pemecahan masalah, (5) memikirkan cara hidup, (6) serta penyesuaian terhadap situasi dan peranan. Dalam hal ini guru kelas diharapkan berperan aktif dalam upaya meningkatkan ketercapaian tugas-tugas perkembangan siswa. Peserta didik pada usia sekolah dasar ini tentu saja sangat membutuhkan pendampingan baik dari orang tua maupun guru disekolah. Tugas perkembangan merupakan suatu tugas yang muncul pada periode dalam rentang kehidupan peserta didik yang akan memberikan pengaruh besar bagi kehidupan peserta didik nantinya.

\section{DAFTAR PUSTAKA}

Azam, U. 2016. Bimbingan dan Konseling Perkembangan di Sekolah (Teori dan Praktik). Yogyakarta: CV Budi Utama. 
Dahir, C. A., \& Stone, C. B. 2012. The Transformed School Counselor. Brooks/Cole, Cengage Learning.

Gibson, R.L., \& Mitchell, M.H. 2011. Bimbingan dan Konseling. Yogyakarta: Pustaka Pelajar. Diterjemahkan dari Introduction to Counseling and Guidance. First publisher 2008 by Pearson Prentice Hall. Pearson education, Inc, Upper Saddle River, New Jersey.

Gilmore, J.M., \& Durkin, K. 2012. A Critical Review of The Validity of Ego Development Theory and Its Measurement. Journal of Personality Assesment, 77(3),541567

Gumilang, G.S. 2017. Niche Counselor Indonesia dalam Pendidikan Formal. Jurnal Fokus Konsseling. 3(2). 194-204.

Kartadinata, S. 2011. Menguak Tabir Bimbingan dan Konseling sebagai Upaya Pedagogis. Bandung : UPI Press

Latifa, U. 2017. Aspek Perkembangan pada Anak Sekolah Dasar: Masalah dan Perkembangannya. Journal of Multidiscipinary Studies, Vol. 1, No. 2, Hal 186196.

Santrock, J.W. 2013. Life-Span Development.(14 th ed). New York: Mc Graw-Hill.

Virani, I.A.D., Riastini, P.N,dan Suarjana,M. 2016. Deskripsi Sikap Sosial pada Peserta Didik Kelas IV SD Negeri Penarukan Kecamatan Buleleng Kabupaten Buleleng. e-Journal PGSD Universitas Pendidikan Ganesha Vol.4, No.1, Hal.1-11.

Yusuf, S. 2014. Psikologi Perkembangan Anak dan Remaja. Bandung: PT Remaja Rosdakarya. 